\title{
Removal of corallivorous snails as a proactive tool for the conservation of acroporid corals
}

Corallivorous snail feeding is a common source of tissue loss for the threatened coral Acropora palmata, accounting for roughly one-quarter of tissue loss in monitored study plots over seven years. In contrast with larger threats such as bleaching, disease, or storms, corallivory by Coralliophila abbreviata is one of the few direct sources of partial mortality that may be locally managed. We conducted a field experiment to explore the effectiveness and feasibility of snail removal. Long-term monitoring plots on six reefs in the upper Florida Keys were assigned to one of three removal treatments: 1) removal from A. palmata only, 2) removal from all host coral species, or 3) no-removal controls. During the initial removal in June 2011, 436 snails were removed from twelve $150 \mathrm{~m}^{2}$ plots. Snails were removed three additional times during a seven month "removal phase", then counted at five surveys over the next 19 months to track recolonization. At the conclusion, snails were collected, measured, and sexed. Before-After-Control-Impact analysis revealed that both snail abundance and feeding scar prevalence were reduced in removal treatments compared to the control, but there was no difference between removal treatments. Recolonization by snails to baseline abundance is estimated to be 3.7 years and did not differ between removal treatments. Recolonization rate was significantly correlated with baseline snail abundance. Maximum snail size decreased from $47.0 \mathrm{~mm}$ to $34.6 \mathrm{~mm}$ in the removal treatments. The effort required to remove snails from A. palmata was 30 diver minutes per $150 \mathrm{~m}^{2}$ plot, compared with 51 minutes to remove snails from all host corals. Since there was no additional benefit observed with removing snails from all host species, removals can be more efficiently focused on only A. palmata colonies, and in areas where $C$. abbreviata abundance is high, to effectively conserve $A$. palmata in targeted areas. 
1 D. E. Williams ${ }^{1,2}$, M. W. Miller ${ }^{2}$, A. J. Bright ${ }^{1,2}$, C. M. Cameron ${ }^{1,2}$

\section{Author Addresses:}

$3{ }^{1}$ Cooperative Institute for Marine and Atmospheric Studies, Rosenstiel School of Marine and Atmospheric

4 Science, University of Miami, 4600 Rickenbacker Cswy, Miami, FL 33149 USA

$5{ }^{2}$ Southeast Fisheries Science Center, NOAA-National Marine Fisheries Service, 75 Virginia Beach Dr.,

6 Miami, FL 33149 USA

7 dana.williams@noaa.gov 


\section{Introduction}

9 Predator control as a management strategy is most commonly considered for invasive

10 predators (Barbour et al. 2011; Baxter et al. 2008; Morris Jr et al. 2011) or outbreaks of endemic

11 predators (Sanz-Aguilar et al. 2009; Yamaguchi 1986). Previous attempts to cull corallivores,

12 specifically Acanthaster planci, have largely been aimed at localized outbreaks with the goal of

13 preserving coral tissue over a large area (Yamaguchi 1986). These efforts have been deemed

14 ineffective due to the large numbers and migrating aggregations of these predators (Johnson et al.

15 1990; Yamaguchi 1986). However, removal of a relatively sedentary predator from targeted

16 populations of a threatened coral species has not been evaluated.

17 Ecological theory on predator-prey dynamics can provide insight on situations when predator

18 removal may be effective in protecting prey. Sinclair et al. (1998) present a framework whereby

19 controlling natural predators may improve the outcome for management of declining or

20 reintroduced populations of threatened species. In this framework, the appropriate scale of

21 intervention depends on the functional and numerical response of predators to changing prey

22 abundance. In cases where the effects of predation are depensatory and prey abundance is so low

23 that they are vulnerable to stochastic events, predator control could be beneficial to prey

24 populations (Sinclair et al. 1998). Rotjan and Lewis (2008), in a review of corallivory, suggest

25 that the rapid pace of coral decline over the past two decades, largely from factors other than

26 predation, may have indeed reached a depensatory threshold such that predation is exerting undue

27 influence and potentially compromising coral reef resilience.

28 On reefs in the western Atlantic, the dominant framework builder, Acropora palmata, is

29 preyed upon by the corallivorous snail, Coralliophila abbreviata. Although disease, storms and

30 bleaching have largely driven the range-wide decline of $A$. palmata populations, snail predation is 
31 recognized as one of the top three proximal threats to the persistence and recovery of A. palmata

32 populations (Bruckner 2002; Williams \& Miller 2012). In the upper Florida Keys, there has been

33 a 50\% decline in A. palmata tissue abundance since 2004. Although the main culprit has been

34 disease, feeding by C. abbreviata accounted for an estimated one-quarter of the observed $A$.

35 palmata tissue loss (Williams \& Miller 2012). As A. palmata populations decline, snails have

36 been observed to become more concentrated on the remaining A. palmata (Baums et al. 2003a;

37 Bruckner 2000; Bruckner et al. 1997; Williams \& Miller 2012) rather than declining themselves,

38 suggesting increasing per capita impact on prey.

39 Coralliophila abbreviata preys on multiple coral host species including acroporids, Orbicella

40 spp., Diploria spp. Colpophylia natans, Agaricia spp. and occasionally other mounding coral

41 species (Miller 1981). Snails found on A. palmata are larger, older, have higher fecundity

42 (Johnston \& Miller 2007) and consume more coral tissue than on other coral host species

43 (Bruckner 2000). These snails are typically found in groups (Baums et al. 2003a; Bruckner 2000;

44 Bruckner et al. 1997) feeding on coral tissue, leaving behind a feeding scar of exposed skeleton.

45 They are relatively sedentary, often remaining on a prey colony until no living tissue remains, at

46 which point they migrate to a neighboring colony (Bruckner 2000; Williams \& Miller 2012).

47 Individual snails can consume up to $16 \mathrm{~cm}^{2}$ of tissue per day (Baums et al. 2003b; Brawley \&

48 Adey 1982), though they do not feed continuously throughout the year at that rate (Bruckner et

49 al. 1997). In addition to directly removing A. palmata tissue during feeding, C. abbreviata may

50 indirectly affect corals by way of vectoring disease (Williams \& Miller 2005) or attracting other

51 predators such as butterflyfish (Brawley \& Adey 1982) and Hermodice carunculata (DEW, pers

52 obs). Thus, C. abbreviata has substantial direct and potential indirect effects on A. palmata.

53 Because this predator has low mobility and a relatively long lifespan (up to 15 years; Johnston \&

54 Miller 2007), it may be feasible to locally reduce their abundance to conserve A. palmata tissue. 
55 Acropora palmata was listed as threatened under the US Endangered Species Act (NMFS

562006 ; 2012) based on devastating declines throughout its range. The ESA listing carries with it a

57 mandate to pursue management actions to foster recovery of the species (ESA, section 4f).

58 Although predation is not the primary factor causing decline of this species, recent trajectories

59 suggest it may be a fundamental factor inhibiting recovery and, at present, predation may be the

60 most locally tractable threat. Even in regions where A. palmata is relatively rare, such as the

61 Florida Keys, its distribution is clumped making targeted removal efforts logistically feasible.

62 Therefore, ecological, legal and management conditions all point to the removal of C. abbreviata

63 as a potential conservation action that could be feasible at the local level. Earlier work (Miller

64 2001) showed that removing C. abbreviata snails on a colony scale can conserve A. palmata

65 tissue, but nothing is known about the effectiveness in terms of recolonization rates or on a larger

66 'reef scale'. The current study utilized long-term fixed monitoring plots of A. palmata colonies to

67 conduct experimental C. abbreviata (here after 'snail') removals to 1) determine the rate at which

68 snails recolonize $A$. palmata colonies, 2) evaluate detectable impacts on the host $A$. palmata

69 population, 3) compare the size distribution of recolonizing versus original snail populations and

70 4) evaluate the effort required for removal by resource managers.

\section{Methods}

72 Long-term Acropora palmata demographic monitoring plots (7-m radius) at six shallow sites

73 in the upper Florida Keys National Marine Sanctuary (FKNMS) reef tract were used to

74 implement a Before-After-Control-Impact (BACI) type design (Green 1979; Smith 2006) to

75 evaluate the effects of snail removal. This design is useful in natural settings because initial

76 variation among individual plots can be partitioned from treatment effects by comparing each

77 plot's trajectory over time (before vs. after a manipulation) among plots subjected to different 
78 treatments. Each site included three plots which were haphazardly assigned a designation of one

79 to three when initially established for monitoring (one to six years prior to the start of the

80 experiment). Three snail removal treatments were assigned according to plot number: plots

81 numbered ' 1 ' had snails removed from A. palmata colonies only (“Ap Only"); plots numbered '2'

82 had snails removed from all host corals in the plot ("All Hosts"; mainly A. palmata, Diploria

83 spp., Orbicella spp. and Colpophylia natans), and plots numbered '3' were designated "Control"

84 in which snails were counted on the host corals in the plots, but were not removed. Thus, the

85 assignment of plots to treatments, though not fully random, was based on a haphazardly-assigned

86 numbering scheme applied years before with no anticipation of conducting the present

87 experiment.

88 Removal

89 This experiment proceeded in two phases. The first, 'removal phase' evaluated short-term

90 reinfestation of the A. palmata colonies, and consisted of three removals beginning with an

91 'initial removal' of snails that provided the 'baseline' snail abundance and ending with a 'final

92 removal'. Three removals were implemented during this phase according to logistic

93 considerations. The second, 'recolonization phase' evaluated the 'effect duration' which is the

94 projected time to reach the baseline snail abundance following a one-time removal effort. This

95 'recolonization phase' consisted of five surveys beginning after 'final removal' and ending at the

96 'final survey' when the snails were collected for analysis.

97 Removal of snails from host corals was performed by two SCUBA divers that were

98 experienced ( $>5$ years) in finding this somewhat cryptic gastropod species. Search procedures

99 included tactile and visual examination of colony margins and undersides as C. abbreviata are

100 typically encrusted by algae and therefore not visually apparent. Individual host colonies were

101 searched, and when snails were found, the diver recorded the host species and number of snails

102 on the colony. In the removal plots, snails were then removed and placed in separate zip-top bags 
103 according to host species. Snail shell length was measured to the nearest $0.1 \mathrm{~mm}$ using Vernier

104 calipers. Due to the high abundance and small size of Agaricia spp. colonies, it was not feasible

105 to systematically locate all the colonies. However, when Agaricia colonies were encountered in

106 the All Hosts and Control plots, they were searched, and snails found in the All Host plots were

107 removed. Initial removal was conducted during 14-16 June 2011 and the number of snails found

108 was considered the 'baseline' snail abundance for each plot.

109 Snails were removed from all A. palmata colonies in the treatment plots again in early July

110 2011, September 2011 and January 2012 ('removal phase'). Thereafter, snails found on $A$.

111 palmata were counted but not removed in May 2012, September 2012, January 2013, May 2013

112 and August 2013 ('recolonization phase'). At the final survey in August 2013, all host colonies

113 were measured (length, width, height and \% live) and surveyed for snails in all plots. Snails were

114 collected from all host corals in the All Hosts treatment plots and A. palmata only in the Ap Only

115 treatment plots and measured to compare the recolonized population with the initial population.

116 Shells were crushed to determine the presence (designating males) or absence (designating

117 females) of a penis. The time spent searching the host colonies and removing encountered snails

118 was recorded during the final survey and the averages among plots were used to evaluate the

119 'effort' of each removal treatment.

120 During the removal and recolonization phases, routine monitoring of A. palmata in the study

121 plots continued as described in Williams et al. (2008). Once per year (fall), all A. palmata

122 colonies in each plot were counted and the length, width and height were measured (using a

123 meter stick), and \% live tissue was visually estimated by a single observer (DEW; see Williams et

124 al. 2006, 2008, for detailed survey protocols). Tissue abundance was estimated as a live area

125 index (LAI), calculated by taking the colony's average dimension (average of length, width and

126 height) squared and multiplying it by the visual estimate of \% live tissue cover. The LAI is 
127 summed for all colonies to get total tissue abundance for the $150-\mathrm{m}^{2}$ study plot. Three times per

128 year a randomly selected subset of tagged A. palmata colonies was further assessed for size, $\%$

129 live tissue and presence of disease, snails and snail feeding scars. This work was conducted under

130 permit numbers FKNMS-2010-033, FKNMS-2010-130 and FKNMS-2012-030 from the Florida

131 Keys National Marine Sanctuary.

132 Analyses

133 Effectiveness of Removal

134 We examined the total number of snails found on A. palmata colonies in the plot (ApSnails),

135 the tissue abundance (LAI) of all A. palmata in the study plot (ApLAI) and the prevalence of

136 disease and feeding scars among a subset of tagged A. palmata colonies. We used a BACI

137 (Before-After-Control-Impact) design to compare the statistical interaction between time and

138 treatment factors for the removal treatments and control. The total number of ApSnails and the

139 ApLAI was compared among treatments using the initial (June 2011) and final (August 2013)

140 surveys. Because the prevalence of both disease and feeding scars vary temporally (Williams \&

141 Miller 2012), we compared the peak in prevalence from the year before the removal and the

142 subsequent peak observed after the removal. Thus, disease prevalence was compared using fall

1432010 (before) and fall 2011 (after) data and the prevalence of feeding scars were compared using

144 spring 2011 (survey prior to removal) and spring 2012 data (first survey after final removal).

145 Each parameter (ApSnails, ApLAI and prevalence of disease and feeding scars) was rank

146 transformed to meet the assumptions of normality and homoscedasticity, and a repeated measures

147 ANOVA was run on the ranks to look for significant $(\mathrm{p} \leq 0.05)$ within-subject interactions

148 between time (the Before/After factor) and treatments (the Control/Impact factor) indicating that

149 the trend in the measured parameter varied significantly between treatments.

150 Recolonization 
151 We examined the rate at which snails recolonized $A$. palmata colonies in removal plots over

152 the recolonization phase. The number of snails present on $A$. palmata colonies following the final

153 removal in January 2012 was assumed to be zero and the number found at each subsequent

154 survey during this recolonization phase was plotted over time for each study plot and linear

155 regression was used to determine the equation for the line. With " $y$ " set to the baseline snail

156 abundance for that plot, we solved for the projected date $(\mathrm{x})$ that the number of snails found on

157 the A. palmata colonies in that plot would return to its baseline abundance observed at the initial

158 removal. The difference between the projected date and the date of the January 2012 removal was

159 calculated as the treatment 'effect duration' for that plot. A Wilcoxon Matched-Pairs test was used

160 to compare the baseline snail abundance, recolonization rate and effect duration between Ap Only

161 and All Hosts removal treatments paired within site.

162 Snail size

163 In order to compare the population of recolonized versus initial snails, shell length of the

164 collected snails was measured and the data were log transformed to achieve normality. A two-way

165 ANOVA was used to compare shell lengths between the two removal treatments and time (initial

166 removal vs final survey). The size-frequency distributions of males and females at the final

167 survey could not be compared between treatments due to small sample size ( $\mathrm{n} \leq 39$; Table 1$)$, but

168 the proportion of the population that was male was calculated as the number of male snails

169 divided by the total number of snails.

\section{Results}

\section{Removal}

172 Searching the host colonies in each $150-\mathrm{m}^{2}$ study plot required on average 30 diver minutes

173 ( \pm 16 minutes SD) at each removal for $A$. palmata only and an additional 21 diver minutes $( \pm 10$ 
174 minutes SD) when the other host species were searched. A total of 279 snails were removed from

175 A. palmata in the twelve $150-\mathrm{m}^{2}$ removal treatment plots (Table 1), and a total of 157 snails were

176 removed from other hosts in the 'all hosts' treatment plots. The baseline number of snails found

177 on A. palmata in the control plots was notably (though not significantly) lower than in the

178 removal treatment plots. This may be a result of a difference in detection as snails were counted

179 in-place rather than removed in the controls, or it may be attributed to less live A. palmata tissue

180 in the control plots (LAI; Table 1). Regardless of the cause for this difference, the BACI analysis

181 is designed to reduce the effect of any initial differences in plots by evaluating only the change

182 within each plot.

183 The mean number of snails found on $A$. palmata colonies (ApSnails) in the removal plots

184 remained less than five per plot during the removal phase, then gradually increased after

185 removals stopped in January 2012 (Fig. 1). The interaction between time and treatment was

186 significant for both the total number of ApSnails per plot (Fig. 2a; $p=0.042)$ and the prevalence

187 of feeding scars (Fig. 2d; $\mathrm{p}=0.004$ ); for both, the removal treatments declined significantly while

188 the controls remained unchanged. There was no change in tissue abundance (LAI) among all

189 treatments (Fig. 2b). The prevalence of disease was significantly higher in fall 2011 compared to

190 fall 2010 (Fig. 2c; $p=0.016$ ) with no significant treatment effects or interaction.

\section{Recolonization}

192 Despite high variability among individual removal plots, linear regressions of the number of

193 snails found at each survey (Fig. 3) yielded $r$ values $\geq 0.7$ within each plot. Both the baseline

194 abundance of ApSnails and the rate of snail recolonization (regression slopes of 0.002 to 0.050

195 snails $\mathrm{d}^{-1}$ ) varied by an order of magnitude among reefs (Fig. 3). When treatment plots were

196 paired by site, neither the baseline abundance of ApSnails nor the recolonization rate differed

197 between treatments. If the Sand Island pair is excluded as an outlier (based on the extreme

198 number of snails found in the Sand Island All Hosts plot, Table 1), then the baseline number of 
199 snails still does not differ between treatments, but the difference in recolonization rate between

200 treatments becomes marginally significant (Wilcoxon, $\mathrm{Z}=2.02, \mathrm{n}=5, \mathrm{p}=0.043$ ). The baseline

201 snail abundance and recolonization rate were highly correlated across all removal plots (Fig. 4).

202 Overall, calculated 'effect durations' ranged from 1.3 to 5.9 years (Fig. 3) with an overall average

203 of $3.7 \pm 1.4( \pm \mathrm{SD})$ years. Effect duration did not differ significantly between Ap Only removal

$204(3.4 \pm 1.4$ years; mean \pm SD) and the All Hosts removal $(4.0 \pm 1.4$ years; mean \pm SD) treatments

205 (Wilcoxon, $\mathrm{Z}=0.31, \mathrm{n}=6, \mathrm{p}=0.8$ ).

206 Size frequency/Sex ratios

207 A two-way ANOVA on log-transformed shell lengths (size) was used to compare the

208 recolonized versus initial ApSnail populations between the two removal treatments (Fig. 5).

209 Mean shell length was significantly larger at the initial $(24.4 \mathrm{~mm} \pm 7.8 \mathrm{~mm}$, pooled mean $\pm \mathrm{SD}$;

$210 \mathrm{~F}_{1,465}=8.61, \mathrm{p}=0.003$; Fig. $\left.5 \mathrm{a}-\mathrm{b}\right)$ compared to the final $(22.1 \mathrm{~mm} \pm 5.7 \mathrm{~mm}$, pooled mean $\pm \mathrm{SD}$;

211 Fig. 5c-d) surveys but not between the two removal treatments $\left(\mathrm{F}_{1,465}=1.09, \mathrm{p}=0.3\right)$ and there

212 was no significant interaction between time and treatment factors $\left(\mathrm{F}_{1,465}=0.16, \mathrm{p}=0.7\right)$. A

213 separate two-way ANOVA was also used to compare the initial and final log-transformed shell

214 lengths between ApSnails (pooled removal treatments) and the snails collected from other host

215 corals in the All Hosts treatments (Fig. 6). Snails collected from other host corals were

216 significantly smaller $\left(18.8 \mathrm{~mm} \pm 3.6 \mathrm{~mm}\right.$, mean $\left.\pm \mathrm{SD} ; \mathrm{F}_{1,710}=103.58, \mathrm{p}<0.001\right)$ than those

217 collected from A. palmata $(24.4 \mathrm{~mm} \pm 7.8 \mathrm{~mm}$, pooled mean $\pm \mathrm{SD})$, and the snails collected at

218 the initial survey were significantly larger $\left(22.5 \mathrm{~mm} \pm 7.2 \mathrm{~mm}\right.$, pooled mean $\pm \mathrm{SD} ; \mathrm{F}_{1,710}=16.83$,

$219 \mathrm{p}<0.001)$ than those collected at the final survey $(20.3 \mathrm{~mm} \pm 5.9 \mathrm{~mm}$, pooled mean $\pm \mathrm{SD})$, but

220 there was no significant interaction $\left(\mathrm{F}_{1,710}=0.23, \mathrm{p}=0.6\right)$ between host and time factors.

221 At the final survey, the proportion of males among ApSnails in the Ap Only treatment was

2220.66 (54 males and 28 females) and 0.74 (52 males and 18 females) in the All Hosts treatment.

223 Unfortunately, we do not have gender ratios for the initial population, but as larger snails are 
224 known to be female in this protandrous species (Johnston \& Miller 2007), the larger snail sizes of

225 the initial population would be expected to reflect a lesser proportion of males relative to the final

226 population.

\section{Discussion}

228 Corallivorous snail removal was effective in significantly decreasing both snail abundance

229 and the prevalence of feeding scars observed 19 months following the removal. Consequent

230 declines in disease prevalence and a parallel enhancement of total tissue abundance (LAI) might

231 be expected, but both of these factors are strongly influenced by a multitude of additional known

232 and unknown factors, thereby decreasing the ability to detect these parallel changes in the present

233 study. However, based on the significantly lower prevalence of feeding scars we can deduce that

234 less tissue was consumed by snails (Miller 2001). Further evaluation of the effects of snail

235 removals should focus on the performance of the A. palmata stand over a longer duration than

236 was possible in this study.

237 The recolonization rate calculations project full recolonization to the baseline abundance of

238 snails over nearly a 4-year period. High site-specific variability was observed in baseline

239 abundance and recolonization rate. In some plots, the rate of snail arrival on A. palmata colonies

240 may accelerate over time (Fig. 3), which is consistent with the aggregating behavior of snails

241 (DEW, pers obs). Thus the extrapolated 'effect duration' is an estimate and might differ in reality

242 due to stochastic events or a non-linear response not observed during the duration of the

243 experiment.

244 At the final survey, the average size of recolonizing snails was smaller than at the initial

245 removal. Though the decrease in mean snail size was modest, the larger sized ApSnails ( $\geq 35$

$246 \mathrm{~mm}$ ) were not observed to recolonize at all (Fig. 5) over the 19-month study period. At the initial 
247 removal, the maximum snail size was $47.0 \mathrm{~mm}$ and at the final survey the maximum was 34.6

$248 \mathrm{~mm}$. Tissue consumption by smaller snails is expected to be less than for larger snails (Baums et

249 al. 2003b; Bruckner 2000; Hayes 1989); thus, although this portion of the size distribution

250 represented approximately $10 \%$ of the population, these larger snails likely were inflicting greater

251 than $10 \%$ of the tissue loss associated with snail predation.

252 In addition to the direct impact of feeding, fecundity is disproportionately higher in these

253 larger snails (Johnston \& Miller 2007). At the initial removal, there were 42 ApSnails found with

254 a shell length $>34.6 \mathrm{~mm}$. Based on the relationship between shell length and veliger production

255 (Johnston \& Miller 2007), we can estimate that these 42 snails, assuming they were all females,

256 would have produced $>715,000$ veligers in one reproductive cycle (clutch). For comparison, if we

257 look at the largest $10 \%$ of the final size distribution (females ranging from 29.8 to $34.6 \mathrm{~mm}$ ),

258 these 17 females are expected to yield approximately 155,000 veligers in one reproductive cycle.

259 In fact, all 46 female ApSnails found at the final survey combined would be predicted to yield

260280,000 veligers in one clutch. Thus, the combination of fewer snails and the shift to smaller

261 sizes could potentially decrease snail reproductive output by more than $50 \%$. In the 3.7 years

262 projected for full recolonization, it is possible that the snail size distribution will also shift back to

263 the baseline size. Based on the size-age relationship reported by Johnston \& Miller (2007), the

264 largest individual observed at the start of the experiment (i.e., $47 \mathrm{~mm}$ ) might be approximately 15

265 years old while the maximum size observed at the final survey would be expected to be

266 approximately 9 years old.

267 Individuals recolonizing A. palmata colonies appear to be primarily from surrounding reef

268 substrate rather than larval recruits. The smallest recolonizing individuals found on A. palmata

269 were $8 \mathrm{~mm}$, and are expected to be $\sim 3$ years old (Johnston \& Miller 2007), which is significantly

270 older than the 1.5 years duration of the recolonization phase in this experiment (January 2012 - 
271 Aug 2013). This suggests that these smallest snails may have been present but not detected at the

272 time of the removal, hence were not new larval recruits. If other host corals were the predominant

273 source of snails that recolonized A. palmata colonies, then we would expect a difference in size

274 distribution and numbers of recolonizing snails between the two removal treatments (Fig. 5c-d),

275 which was not the case. Although the snails on other host corals in the Ap Only treatment were

276 not measured at the start of the experiment, they would likely have had the same size distribution

277 as those collected in the All Hosts treatment at the start (Fig. 6b). Presumably, if these other host

278 coral species were the source of recolonizing ApSnails, then the size distribution of ApSnails in

279 the Ap Only treatment at the final survey (Fig. 5c) would be similar to the distribution of the

280 snails collected from other host corals at the initial removal (Fig. 6b). Specifically, there were

281 relatively few snails larger than $24 \mathrm{~mm}$ on the other host corals, yet more than one-third of

282 recolonizing snails were larger than $24 \mathrm{~mm}$ (Fig. 6c). Instead, the size distribution of recolonizing

283 snails in both removal treatments looks the same (Fig. 5c-d), suggesting that the snails found on

284 A. palmata are not migrants from other host corals.

285 During the removal phase, the average number of snails found at the subsequent survey did

286 not diminish (Fig. 1; mean of $\sim 2$ to 5 snails), therefore it seems that the pool of colonizing snails

287 was not depletable by reasonable removal efforts at these temporal and spatial scales. This effort

288 was intended to reflect what could reasonably be achieved in a conservation application, thus

289 only coral colonies of known snail-hosting species were systematically searched. Although the

290 colony searches were thorough, snails on adjacent reef substrates between colonies would not

291 have been detected until they recolonized an A. palmata colony at a subsequent survey.

292 In our experiment, no significant added benefit was derived from the additional effort

293 required to remove snails from all host corals versus $A$. palmata only (Fig. 1). Removing snails

294 from $A$. palmata only required 30 diver minutes versus 51 diver minutes for removal from all 
295 hosts. The density of other host colonies in the plots was $5 \pm 4.9$ colonies (mean \pm SD) and a total 296 of $21 \pm 15.6$ (mean \pm SD) snails per plot were found on these other host colonies. If the site with

297 the unusually high number of snails was excluded, the recolonization rates were marginally faster 298 in plots where the snails were not removed from other hosts. It is possible that in areas where the 299 other hosts species are more abundant or are harboring greater numbers of snails, the additional 300 effort to remove them would be worthwhile, though more costly. However, the targeted removal 301 of snails from Acropora spp. hosts only yields clear benefits yet allays concerns about potential 302 unintended consequences of removal such as selection for earlier age of sex change, or potential 303 trophic impacts on populations preying on the snails.

304 In planning snail removal as an A. palmata conservation effort, the cost (diver time) and 305 benefit (reduced snail load) must be balanced. With the mean effect duration of nearly four years, 306 one strategy could be to perform a removal at four year intervals. However, our results show high 307 between-site variability in snail abundance; thus the strong correlation of recolonization rate with 308 initial snail load (Fig. 4) suggests that the frequency or need for subsequent removals may be 309 indicated by the number of snails that are found at the initial removal. In another view, the mean 310 rate of snail recolonization appears to increase after one year (Fig. 1), so a single annual removal 311 might be a useful target, at least for areas of high snail abundance ( $>0.2$ snails $\mathrm{m}^{-2}$ of reef area).

312 Corallivorous snails feed more actively in warmer months (Al-Horani et al. 2011), so snail 313 removal efforts could be more efficient during the summer. Additionally, although their egg

314 production cycle is not well established, it is more common to find egg cases with mature 315 veligers in mid-to-late summer (DEW, pers obs); thus, removal prior to that may reduce larval 316 production.

317 Most of our sites were located on spur and groove formations on the shallow fore reef. 318 However, our study plots did not occupy the full extent of a reef 'spur', leaving contiguous reef 
319 areas populated with snails. In practice, removal from all corals on a contiguous spur may further

320 prolong the effect duration of the removal. This may not be practical in areas where there are not

321 natural breaks in reef structure, but removal from contiguous stands of A. palmata may be

322 possible. The effect of $A$. palmata colony density on snail recolonization rate was not tested in

323 this study; however, other studies have found that C. abbreviata abundance is generally lower in

324 higher density 'thicket'-type stands of A. palmata (Baums et al. 2003a; Bruckner et al. 1997;

325 Miller et al. 2002). Therefore, removal effort could be more efficiently focused on A. palmata

326 stands with intermediate or low colony density rather than dense thickets. Although removing

327 snails is not technically difficult, C. abbreviata is fairly well camouflaged and divers should be

328 trained to recognize them to ensure effective removal and to minimize collection of other non-

329 corallivorous species such as Thais deltoidea that are commonly found around A. palmata.

330 Given the ecologically and legally imperiled status of A. palmata, and the intractability of

331 managing the most severe threats such as disease and climate change, proactive conservation

332 measures that can be implemented at a local level are needed. This experiment demonstrates the

333 effectiveness of snail removal at a local scale with a 30 minute diver investment to reduce

334 corallivore loads over an estimated four year time scale in seven meter radius plots containing $A$.

335 palmata. Given the rarity of $A$. palmata throughout many sections of its range, it is likely that two

336 divers could successfully search for and remove snails over a large area of vulnerable $A$. palmata

337 (i.e., low density stands with high snail loads) with only a few days of effort. While a wide range

338 of conservation and restoration actions are required to address both local and global threats to

339 corals, the removal of corallivorous snails may be used on natural or restored (outplanted)

340 populations to conserve living acroporid coral. 


\section{Acknowledgements}

342 Field assistance by K. Lohr, C. Kiel, and L. Richter is greatly appreciated.

\section{References}

344

345

346

347

348

349

350

351

352

353

354

355

356

357

358

359

360

361

362

363

364

365

366

367

368

369

370

371

372

373

374

375

376

377

378

379

380

Al-Horani FA, Hamdi M, and Al-Rousan SA. 2011. Prey selection and feeding rates of Drupella cornus (Gastropoda: Muricidae) on corals from the Jordanian coast of the Gulf of Aqaba, Red Sea. Jordan Journal of Biological Sciences 4:191-198.

Barbour AB, Allen MS, Frazer TK, and Sherman KD. 2011. Evaluating the potential efficacy of invasive lonfish (Pterois volitans) removals. PLoS ONE 6:e19666.

Baums IB, Miller MW, and Szmant AM. 2003a. Ecology of a corallivorous gastropod, Coralliophila abbreviata, on two scleractinian hosts. I: population structure of snails and corals. Marine Biology 142:1083-1091.

Baums IB, Miller MW, and Szmant AM. 2003b. Ecology of a corallivorous gastropod, Coralliophila abbreviata, on two scleractinian hosts. II. feeding, respiration and growth. Marine Biology 142:1093-1101.

Baxter PWJ, Sabo JL, Wilcox C, McCarthy MA, and Possingham HP. 2008. Cost-effective suppression and eradication of invasive predators. Conservation Biology 22:89-98.

Brawley SH, and Adey WH. 1982. Coralliophila abbreviata: a significant corallivore. Bulletin of Marine Science 32:595-599.

Bruckner AW. 2002. Proceedings of the Caribbean Acropora Workshop: potential application of the U.S. Endangered Species Act as a conservation strategy. NOAA Technical Memorandum NMFS-OPR-24, Silver Spring, MD, p 199.

Bruckner RJ. 2000. Effects of the population dynamics of the corallivorous prosobranch gastropod Coralliophila abbreviata (Lamarck) on coral tissue predation MS Thesis M.S. thesis. University of Puerto Rico.

Bruckner RJ, Bruckner AW, and Williams EHJ. 1997. Life history strategies of Coralliophila abbreviata Lamarck (Gastropoda: Coralliophilidae) on the southeast coast of Puerto Rico. Proceedings of the 8th International Coral Reef Symposium 1:627-632.

Green RH. 1979. Sampling design and statistical methods for environmental biologists: John Wiley \& Sons.

Hayes JA. 1989. The biology and ecology of Coralliophila abbreviata Lamarck (Gastropoda, Coralliophilidae) : the importance of corallivores in the ecology of coral reefs Ph.D. Ph.D. thesis. University of Texas at Austin.

Johnson DB, Moran PJ, and Driml S. 1990. Evaluation of a crown-of-thorns starfish (Acanthaster planci) control program at Grub Reef (central Great Barrier Reef). Coral Reefs 9:167-171.

Johnston L, and Miller MW. 2007. Variation in life-history traits of the corallivorous gastropod Coralliophila abbreviata on three coral hosts. Marine Biology 150:1215-1225.

Miller AC. 1981. Cnidarian prey of the snails Coralliophila abbreviata and C. caribaea (Gastropoda: Muricidae) in Discovery Bay, Jamaica. Bulletin of Marine Science 31:932934. 
381

382

383

384

385

386

387

388

389

390

391

392

393

394

395

396

397

398

399

400

401

402

403

404

405

406

407

408

409

410

411

412

413

Miller MW. 2001. Corallivorous snail removal: evaluation of impact on Acropora palmata. Coral Reefs 19:293-295.

Miller MW, Baums IB, Williams DE, and Szmant AM. 2002. Status of Candidate coral, Acropora palmata, and its snail predator in the upper Florida Keys National Marine Sanctuary: 1998-2001. NOAA Technical Memorandum, Miami, FL, p 26.

Morris Jr JA, Shertzer KW, and Rice JA. 2011. A stage-based matrix population model of invasive lionfish with implications for control. Biological Invasions 13:7-12.

NMFS, 2006, Endangered and threatened species: final listing determinations for Elkhorn coral and Staghorn coral. Federal Register:71 FR 26852.

NMFS, 2012, Endangered and Threatened wildlife and plants: proposed listing determinations for 82 reef-building coral species; proposed reclassification of Acropora palmata and Acropora cervicornis from Threatened to Endangered. Federal Register:77 FR 73220.

Rotjan RD, and Lewis SM. 2008. Impact of coral predators on tropical reefs. Marine Ecology Progress Series 367:73-91.

Sanz-Aguilar A, Martínez-Abraín A, Tavecchia G, Mínguez E, and Oro D. 2009. Evidence-based culling of a facultative predator: efficacy and efficiency components. Biological Conservation 142:424-431.

Sinclair ARE, Pech RP, Dickman CR, Hik D, Mahon P, and Newsome AE. 1998. Predicting effects of predation on conservation of endangered prey. Conservation Biology 12:564575.

Smith EP. 2006. BACI Design. In: El-Shaarawi AH, and Piegorsch WW, eds. Encyclopedia of Environmetrics. Chichester: John Wiley \& Sons, Ltd, 141-148.

Williams DE, and Miller MW. 2005. Coral disease outbreak: pattern, prevalence and transmission in Acropora cervicornis. Marine Ecology Progress Series 301:119-128.

Williams DE, and Miller MW. 2012. Attributing mortality among drivers of population decline in Acropora palmata in the Florida Keys (USA). Coral Reefs 31:369-382.

Williams DE, Miller MW, and Kramer KL. 2006. Demographic monitoring protocols for threatened Caribbean Acropora spp. corals. NOAA Technical Memorandum NMFSSEFSC-543, Miami, FL, p 112.

Williams DE, Miller MW, and Kramer KL. 2008. Recruitment failure in Florida Keys Acropora palmata, a threatened Caribbean coral. Coral Reefs 27:697-705.

Yamaguchi M. 1986. Acanthaster planci infestations of reefs and coral assemblages in Japan: a retrospective analysis of control efforts. Coral Reefs 5:23-30. 


\section{Figure captions}

415 Figure 1 Number of Coralliophila abbreviata found on Acropora palmata per plot (mean $\pm \mathrm{SE}$ ).

416 The initial removal occurred in June 2011, and remaining snails were removed through January

4172012 (removal phase, gray dots) after which they were only counted and left in place during the

418 recolonization phase (solid black dots).

419 Figure 2 Before-After-Control-Impact analysis of a) the total number of Coralliophila

420 abbreviata found on Acropora palmata in a study plot, b) the $A$. palmata tissue abundance as

421 measured by the live area index (LAI, see text), c) the prevalence of white disease on a random

422 subset of A. palmata colonies during the seasonal peak in disease before and after the initial

423 removal, and d) the prevalence of C. abbreviata feeding scars on the random subset of $A$.

424 palmata colonies at the survey prior to the initial removal and one year later. All points are mean

$425 \pm$ standard error. Data were rank transformed for analysis and the p-values based on the

426 transformed data are shown.

427 Figure 3 Number of Coralliophila abbreviata snails found on Acropora palmata in each plot

428 where they were removed from Acropora palmata only (Ap Only) and from all host coral species

429 (All Hosts) following the removal phase of the experiment. The dotted line indicates the baseline

430 number of $C$. abbreviata that were removed from that treatment plot at the start of the experiment

431 in June 2011. 'Effect duration' is the estimated time for the number of snails to reach the baseline

432 (recolonization), according to the regression for each plot. 
433 Figure 4 Recolonization rate (number of snails per day) based on the slope of the linear

434 regressions (Fig. 3) versus the number of snails found on Acropora palmata in each study plot at 435 the initial removal.

436 Figure 5 Size and gender (Sept 2013 only) frequency distribution for the Coralliophila

437 abbreviata snails collected from Acropora palmata host colonies in the a) Ap Only (snails

438 removed from A. palmata only) and b) All Hosts (snails removed from all host coral species)

439 treatments at the initial removal (June 2011) and at the final survey (Sept 2013) for c) Ap Only

440 and d) All Hosts treatments.

441 Figure 6 Size and gender (Sept 2013 only) frequency distribution for the Coralliophila

442 abbreviata snails collected from a) Acropora palmata host colonies and b) other host species at

443 the initial removal (June 2011) and at the final survey (Sept 2013) from c) A. palmata and d) and 444 other host coral species. 


\section{Table 1 (on next page)}

Summary of coral host colonies and Coralliophila abbreviata snails found in the study plots in the initial and final survey.

Observations at each study plot in three experimental treatments: removal of Coralliophila abbreviata snails from Acropora palmata only (Ap Only), from all coral host species (All Hosts) and controls in which snails were counted but not removed. Coral colonies and snails counted at the initial survey in June 2011 and the final survey in August 2013. A. palmata LAI (live area index) is calculated based on colony measurements described in the text. 


\begin{tabular}{|c|c|c|c|c|c|c|c|c|c|c|c|}
\hline \multirow[b]{2}{*}{ Treatment } & \multirow[b]{2}{*}{ Reef } & \multicolumn{2}{|c|}{$\begin{array}{l}\text { A. palmata } \\
\text { colonies }\end{array}$} & \multicolumn{2}{|c|}{$\begin{array}{c}A . \\
\text { palmata } \\
\text { Snails }\end{array}$} & \multicolumn{2}{|c|}{$\begin{array}{c}\text { A. } \\
\text { palmata } \\
\text { LAl }\left(\mathrm{m}^{2}\right)\end{array}$} & \multicolumn{2}{|c|}{$\begin{array}{c}\text { Other } \\
\text { host } \\
\text { colonies }\end{array}$} & \multicolumn{2}{|c|}{$\begin{array}{c}\text { Other } \\
\text { host } \\
\text { snails }\end{array}$} \\
\hline & & Initial & $\begin{array}{l}\text { Fin } \\
\text { al }\end{array}$ & $\begin{array}{c}\text { Initi } \\
\text { al }\end{array}$ & $\begin{array}{c}\text { Fin } \\
\text { al }\end{array}$ & $\begin{array}{c}\text { Initi } \\
\text { al }\end{array}$ & $\begin{array}{c}\text { Fin } \\
\text { al }\end{array}$ & $\begin{array}{c}\text { Initi } \\
\text { al }\end{array}$ & $\begin{array}{c}\text { Fin } \\
\text { al }\end{array}$ & $\begin{array}{c}\text { Initi } \\
\text { al }\end{array}$ & $\begin{array}{l}\text { Fin } \\
\text { al }\end{array}$ \\
\hline \multirow{6}{*}{ Ap Only } & "Carysfort & 32 & $\overline{21}$ & 43 & $\overline{c 16}$ & 8.4 & 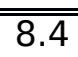 & & 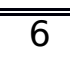 & & $\overline{4}$ \\
\hline & Elbow & 55 & 76 & 27 & 19 & 15.2 & $\begin{array}{c}14 . \\
8\end{array}$ & & 1 & & 0 \\
\hline & French & 42 & 57 & 13 & 7 & 9.7 & $\begin{array}{c}10 . \\
5\end{array}$ & & 19 & & 29 \\
\hline & $\begin{array}{l}\text { Key Largo Dry } \\
\text { Rocks }\end{array}$ & 11 & 11 & 4 & 3 & 1.6 & 0.7 & & 5 & & 9 \\
\hline & Molasses & 11 & 15 & 13 & 20 & 2.5 & 2.3 & & 0 & & 0 \\
\hline & Sand Island & 18 & 21 & 32 & 17 & 2.8 & 4.7 & & 1 & & 1 \\
\hline \multirow{6}{*}{ All Hosts } & Carysfort & 8 & 13 & 17 & 6 & 6.7 & 2.3 & 3 & 3 & 61 & 34 \\
\hline & Elbow & 28 & 31 & 20 & 9 & 5.0 & 4.8 & 2 & 1 & 10 & 3 \\
\hline & French & 29 & 44 & 10 & 6 & 1.4 & 2.1 & 6 & 5 & 39 & 21 \\
\hline & $\begin{array}{l}\text { Key Largo Dry } \\
\text { Rocks }\end{array}$ & 22 & 15 & 2 & 1 & 0.5 & 0.2 & 2 & 2 & 19 & 0 \\
\hline & Molasses & 29 & 40 & 38 & 9 & 3.6 & 4.0 & 7 & 8 & 19 & 25 \\
\hline & Sand Island & 41 & 51 & 60 & 39 & 12.7 & $\begin{array}{c}16 . \\
7\end{array}$ & 1 & 1 & 9 & 4 \\
\hline \multirow{6}{*}{ Control } & Carysfort & 13 & 9 & 16 & 15 & 0.9 & 0.1 & 6 & 4 & 23 & 4 \\
\hline & Elbow & 22 & 29 & 16 & 18 & 4.2 & 3.5 & 4 & 4 & 14 & 6 \\
\hline & French & 24 & 20 & 8 & 5 & 1.9 & 1.2 & 15 & 15 & 29 & 31 \\
\hline & $\begin{array}{l}\text { Key Largo Dry } \\
\text { Rocks }\end{array}$ & 10 & 9 & 11 & 10 & 3.0 & 2.5 & 6 & 6 & 10 & 10 \\
\hline & Molasses & 22 & 31 & 15 & 21 & 8.7 & 8.7 & 7 & 6 & 7 & 8 \\
\hline & Sand Island & 10 & 9 & 4 & 5 & 0.8 & 1.2 & 6 & 4 & 10 & 8 \\
\hline
\end{tabular}


Figure 1

Coralliophila abbreviata abundance in experimental plots

Number of Coralliophila abbreviata found on Acropora palmata per plot (mean $\pm \mathrm{SE}$ ). The initial removal occurred in June 2011, remaining snails were removed through January 2012 (removal phase, gray dots) after which they were only counted and left in place during the survey phase (solid black dots).

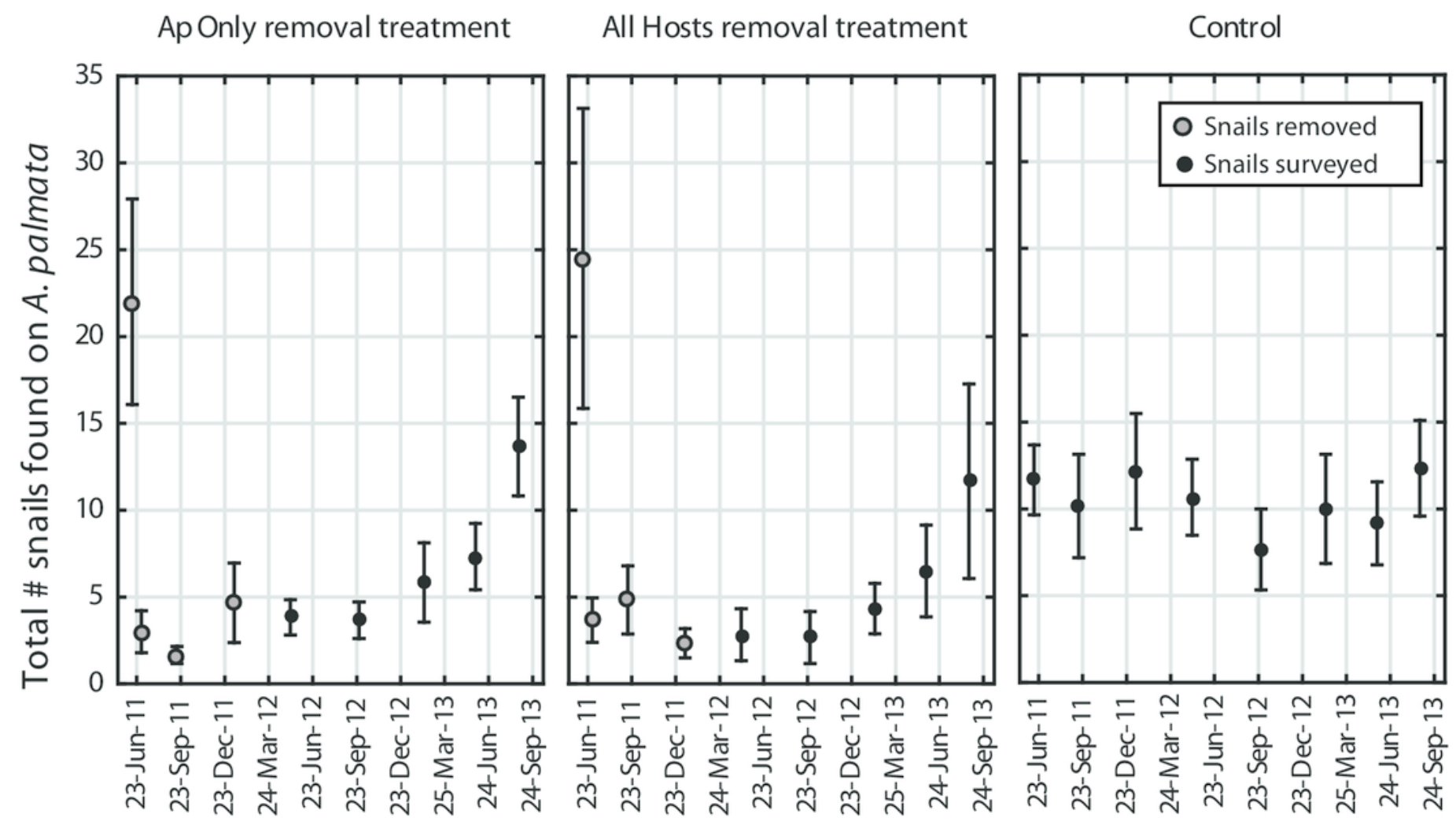




\section{Figure 2}

Before-After-Control-Impact analysis

Before-After-Control-Impact analysis of a) the total number of Coralliophila abbreviata found on Acropora palmata in a study plot, b) the $A$. palmata tissue abundance as measured by the live area index (LAl, see text), c) the prevalence of white disease on a random subset of $A$. palmata colonies during the seasonal peak in disease before and after the initial removal, and d) the prevalence of $C$. abbreviata feeding scars on this random subset of $A$. palmata colonies at the survey prior to the initial removal and one year later. All points are mean \pm standard error. Data were rank transformed for analysis and the p-values based on the transformed data are shown.
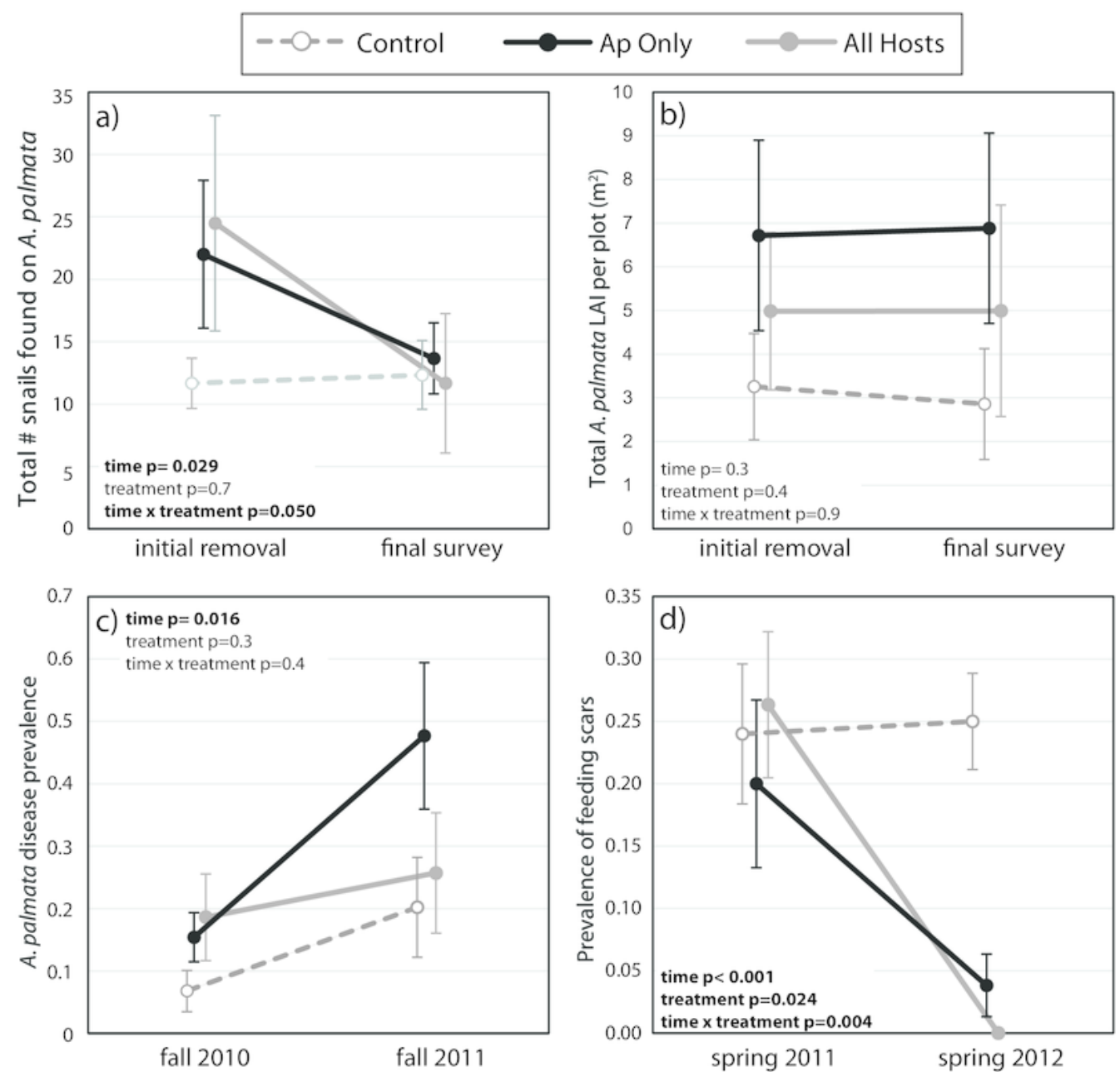


\section{Figure 3}

Recolonization of A. palmata by Coralliophila abbreviata snails

Number of Coralliophila abbreviata snails found on Acropora palmata in each plot where they were removed from Acropora palmata only (Ap Only) and from all host coral species (All Hosts) following the removal phase of the experiment. The dotted line indicates the baseline number of $C$. abbreviata that were removed from that treatment plot at the start of the experiment in June 2011. 'Effect duration' is the estimated time for the number of snails to reach the baseline (recolonization), according to the regression for each plot.

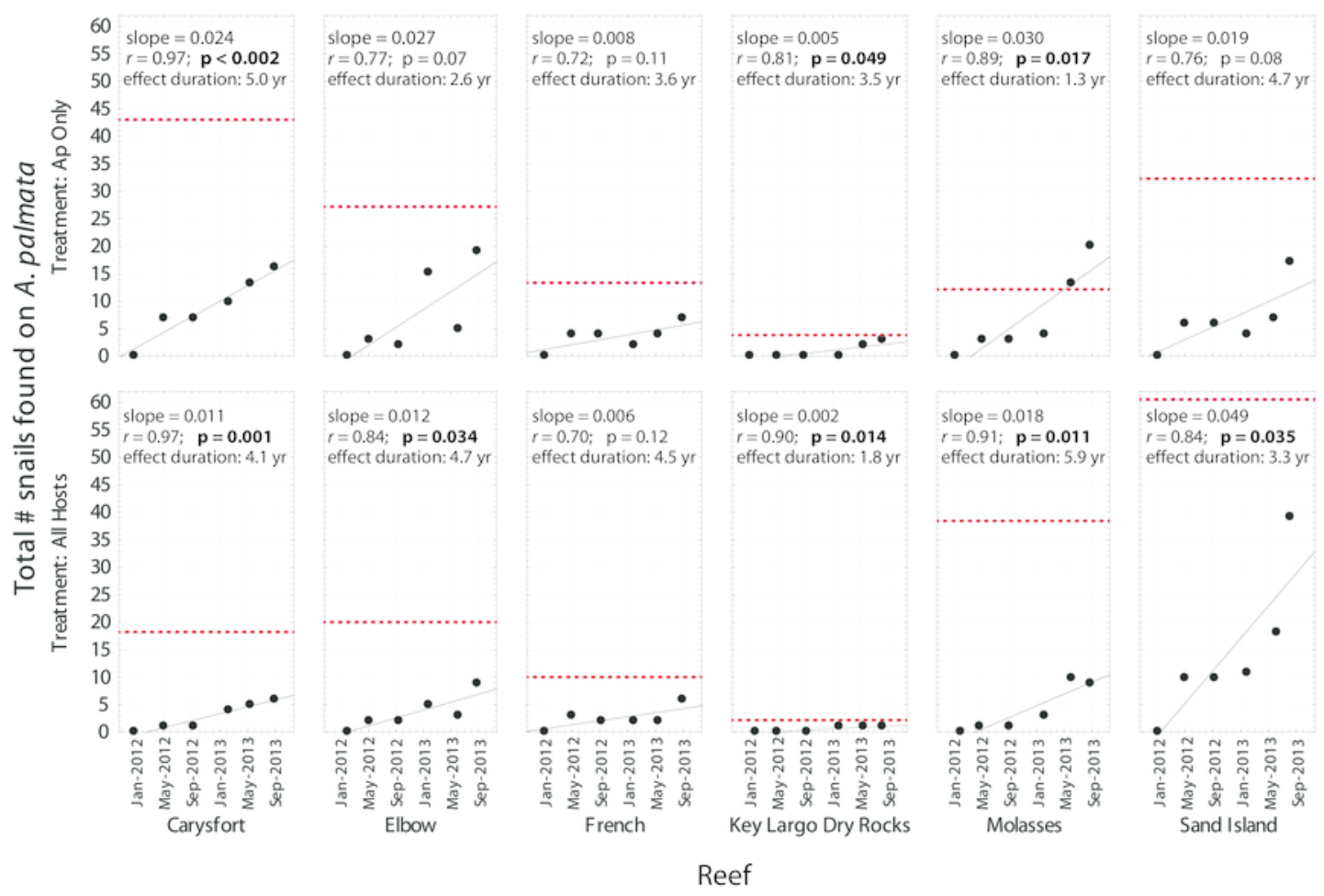


Figure 4

Coralliophila abbreviata recolonization rate

Recolonization rate (number of snails per day) based on the slope of the linear regressions (Fig. 3) versus the number of snails found on Acropora palmata in each study plot at the initial removal 


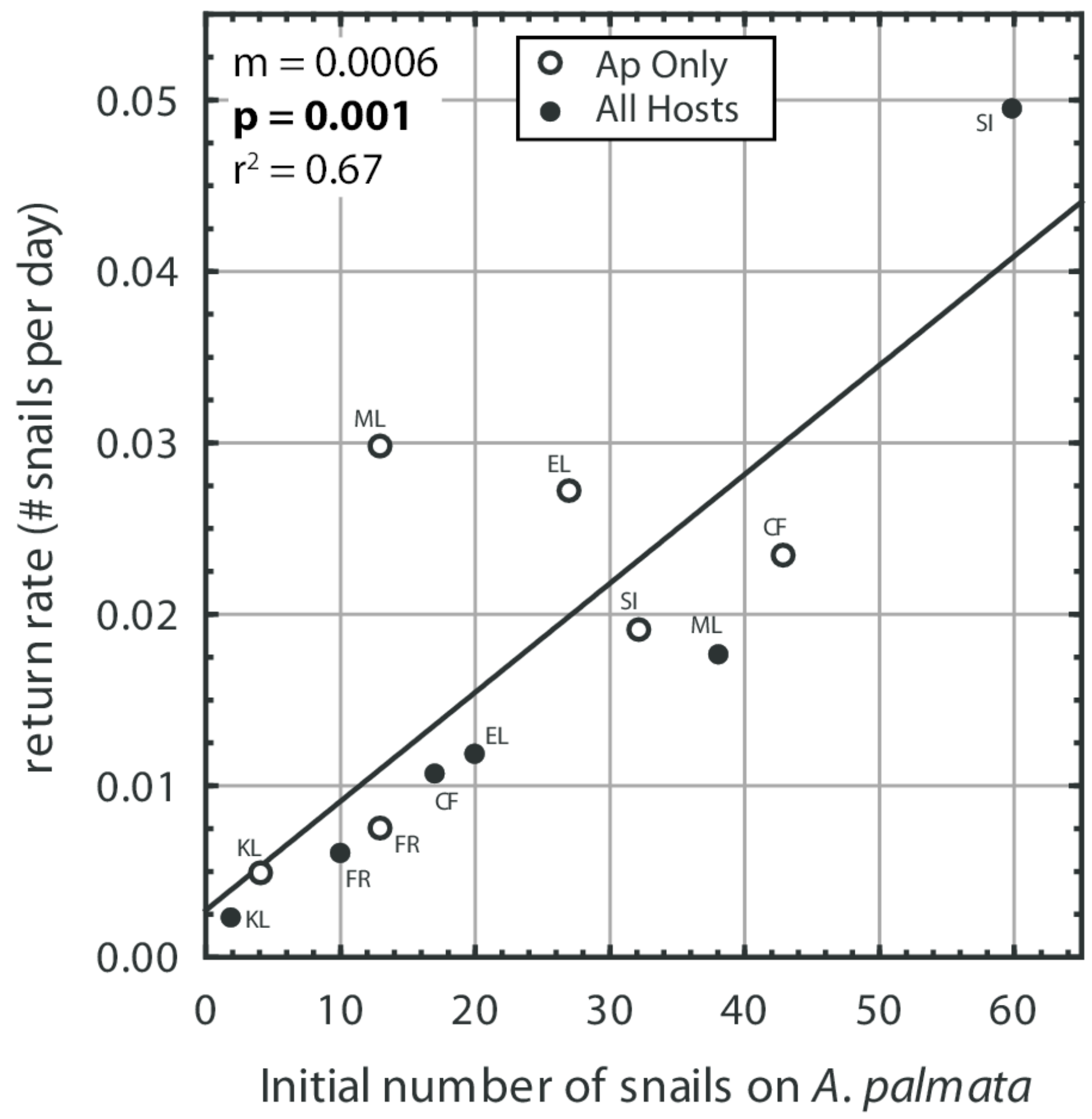


Figure 5

Coralliophila abbreviata size and gender frequency distribution

Size and gender (Sept 2013 only) frequency distribution for the Coralliophila abbreviata snails collected from Acropora palmata host colonies in the a) Ap Only (snails removed from A. palmata only) and b) All Hosts (snails removed from all host coral species) treatments at the initial removal (June 2011) and at the final survey (Sept 2013) for c) Ap Only and d) All Hosts treatments. 

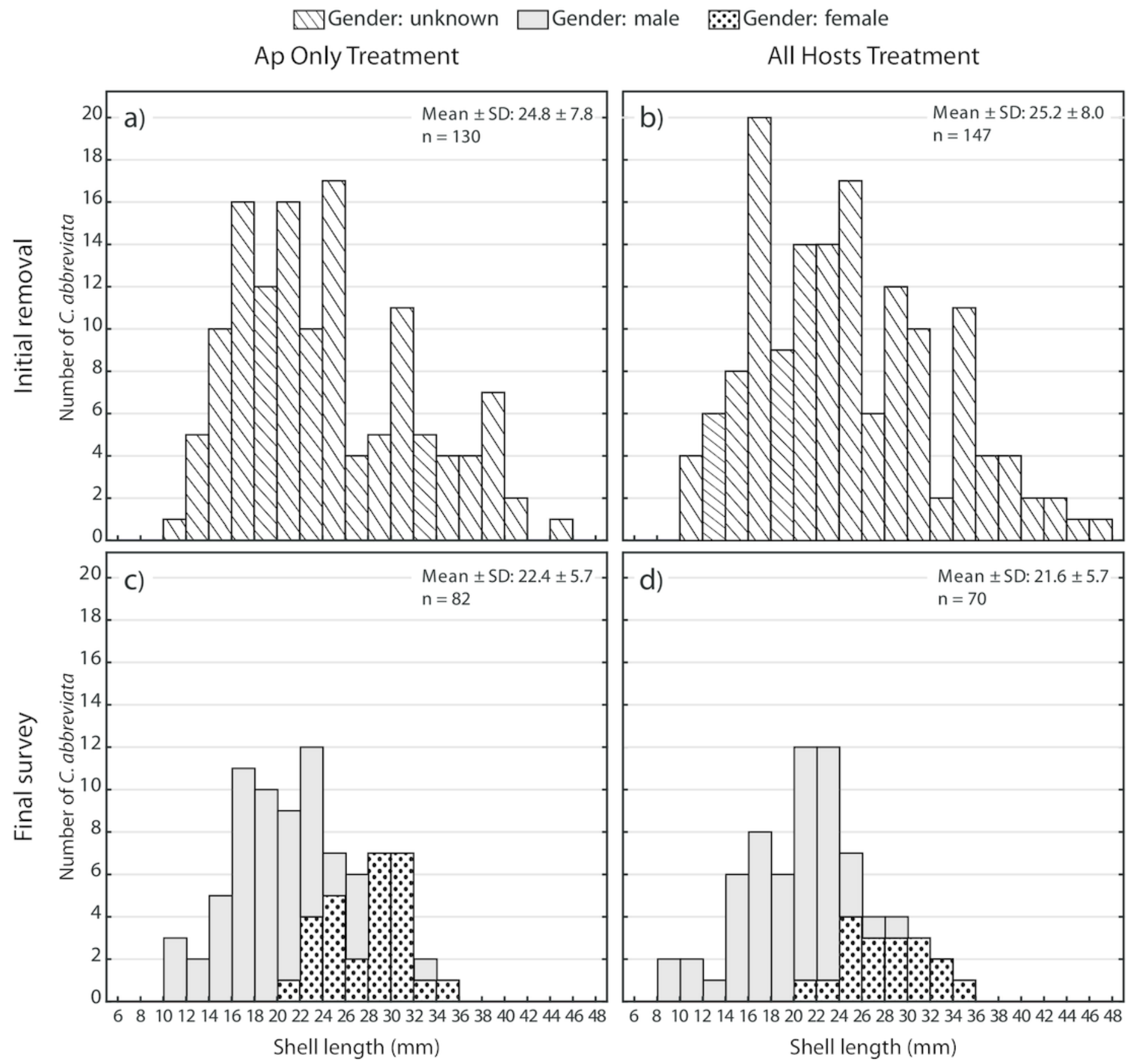


\section{Figure 6}

Coralliophila abbreviata size and gender frequency distribution

Size and gender (Sept 2013 only) frequency distribution for the Coralliophila abbreviata snails collected from a) Acropora palmata host colonies and b) other host species at the initial removal (June 2011) and at the final survey (Sept 2013) from c) A. palmata and d) and other host coral species.

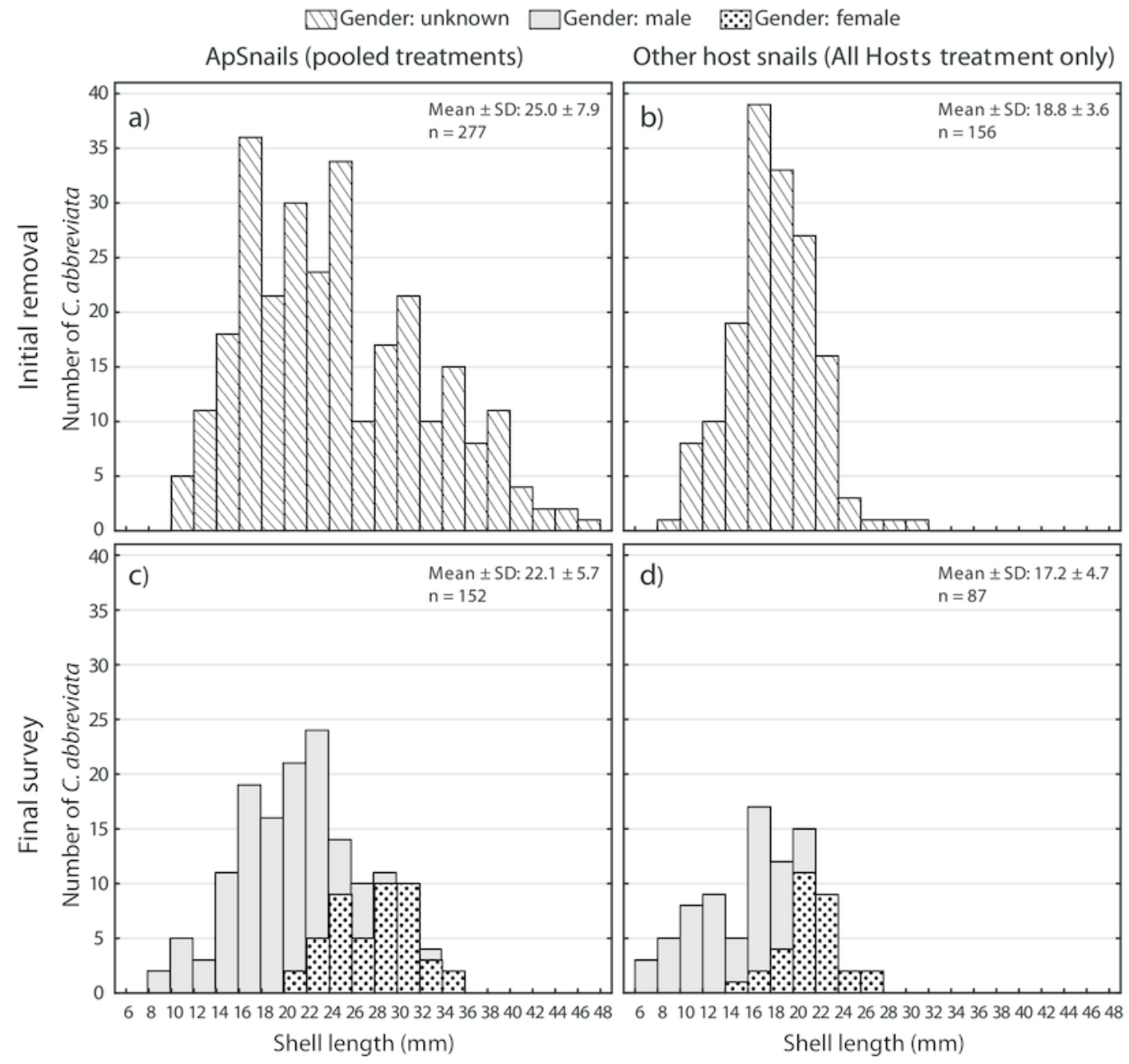

